\title{
MRSA screening and spa gene detection in isolates from healthcare workers at ophthalmology hospital in Egypt
}

\author{
Maha G. Haggag ${ }^{1,2^{*}}$ D, Amal E. Aboelnour ${ }^{3}$ and Mai Al-Kaffas ${ }^{1}$
}

\begin{abstract}
Background: Staphylococcus aureus has a major role in different types of eye infections as conjunctivitis, keratitis, and endophthalmitis. Methicillin-resistant Staphylococcus aureus (MRSA) was almost restricted to hospitals, but its prevalence has been increased in people outside hospitals. The cell wall of Staphylococcus aureus has protein A which can bind to the Fc portion of IgG. This ptnA is encoded by surface protein A of Staphylococcus aureus (spa) gene that contains a highly polymorphic sequence which is composed of repeats of 24-bp. Sequence typing of the spa gene repeat region is used to study the epidemiology of MRSA. The purpose of this study was screening of MRSA strains among healthcare workers (HCWs) in the Hospital of the Research Institute of Ophthalmology (RIO), Giza, Egypt, and detecting spa gene in their DNAs by PCR.

Results: In the present study, 81 samples from healthcare providers in the hospital of the Research Institute of Ophthalmology, Egypt, were screened for MRSA. Out of these 81 samples, 41 isolates (50.6\%) were identified as coagulase-positive Staphylococcus aureus. Twelve staphylococcal isolates were resistant to both oxacillin and cefoxitin, and those were identified as MRSA with a percentage of $14.8 \%$ (12/81). Conventional PCR could detect spa gene in 10 out of 12 DNA MRSA with a percentage of $83.3 \%(10 / 12)$.

Conclusion: In the present study, the prevalence of MRSA in HCWs was $14.8 \%$. Since amplification of spa gene by PCR is a necessary preliminary step for spa typing of MRSA and since using different primers for spa gene amplification might affect PCR results, then proper selection of the primers and thermal cycling reaction conditions are recommended for PCR performance and spa typing.
\end{abstract}

Keywords: S. aureus, MRSA, Epidemiology, HCWs, spa typing, spa primers PCR

\section{Introduction}

Staphylococcus aureus is a crucial bacteria commonly isolated from human infections that range from minor skin and soft tissue infections to life-threatening systemic infections (Liu et al. 2016). Staphylococcus aureus has a major role in different types of eye infections such as conjunctivitis, keratitis, and endophthalmitis. Methicillinresistant Staphylococcus aureus (MRSA) was almost restricted to hospitals and hence termed healthcareassociated (HA) strains, but its prevalence has increased in

\footnotetext{
* Correspondence: mghaggag@gmail.com

${ }^{1}$ Microbiology \& Immunology Unite, Research Institute of Ophthalmology, 2

El Ahram Street, Giza 12557, Egypt

${ }^{2}$ Allergy lab, Research Institute of Ophthalmology, 2 El Ahram Street, Giza

12557, Egypt

Full list of author information is available at the end of the article
}

people outside hospitals which is termed community-associated (CA) strains. Infections with both types are clinically, microbiologically, and genetically different (Ritterband 2013).

MRSA strains are not essentially more virulent than methicillin-sensitive $S$. aureus strains, but some MRSA strains hold factors or genetic elements that may intensify their virulence or may allow them to induce peculiar clinical syndromes (Gordon and Lowy 2008). The cell wall of Staphylococcus aureus has protein A which can bind to the Fc portion of IgG at the complementbinding site thereby preventing complement activation (El-Mishad 2011). Virulence mediated by spa is not only by binding to the Fc of the Ig preventing normal phagocytosis, but also by binding to the Fab site of the B cell receptor blocking the production of antibody specific for 
S. aureus and provoking B cell death (Kobayashi and DeLeo 2013; Keener et al. 2017).

This Fc-binding region, the so-called X-region of protein A gene (spa) contains a highly polymorphic sequence which is composed of repeats of 24-bp. Most epidemic MRSA strains contain more than seven repeats, while most nonepidemic MRSA strains have seven or fewer repeats. It is reasonable that a longer $\mathrm{X}$ region leads to a better exposition of the Fc-binding region of protein $\mathrm{A}$ and hence increasing colonization of host surfaces and responsible for the epidemic phenotype (Frénay et al. 1994, 1996).

For epidemiological investigations, prevention and control of infections molecular typing is crucial. Choosing the method for molecular typing is based on being consistent, cost-effective, quick, simple, and easy to understand results. Sequence typing of the spa gene repeat region was used to study the epidemiology of MRSA (Harmsen et al. 2003; Fasihi et al. 2017).

Strain typing of microbial pathogens aims to detect genetic microvariation for outbreak investigations and to sign genetic macrovariation for phylogenetic identification and population-based analyses. However, there has been no evidence that one genetic character can be used efficiently for indexing micro-and macro-variation until Koreen et al. (2004) in their study showed that genetic analysis of the repeat region of protein A (spa typing) was able to measure genetic variations that accumulate both rapidly and slowly (micro- and macro-variation) by two independent mechanisms, so this genetic character of repeat region of protein $\mathrm{A}$ is efficient for both local and global long-term epidemiologic- and populationbased studies.

The aim of this study was screening of MRSA strains among healthcare workers (HCWs) in the hospital of the Research Institute of Ophthalmology, Giza, Egypt, and detection of spa gene in their DNAs by PCR.

\section{Material and methods}

The work in the present study involved 81 nasal swabs collected from healthcare providers including doctors, nurses, and workers in the hospital of the Research Institute of Ophthalmology, Egypt.

The first step was identification of MRSA isolates as follows.

The specimens were cultured on nutrient agar, blood agar, and mannitol salt agar and incubated at $37^{\circ} \mathrm{C}$ for 18-24 h. Hemolytic colonies from blood agar and yellow colonies from mannitol salt agar and nutrient agar were identified microscopically as staphylococci.

Coagulase test was done by Dry spot Staphytect Plus which is a latex agglutination slide test for identification of Staphylococcus aureus by detection of clumping factor, Protein, A and capsular polysaccharides, the latter may be held by MRSA and may mask both the clumping factor and protein A (Fournier et al. 1989). The tested colony was emulsified in a drop of distilled water onto the reagent of the card and mixed, and agglutination within a minute identifies coagulase-positive Staphylococcus aureus (Fig. 1).

MRSA was identified by disc diffusion method according to the Clinical Laboratory Standards Institute (CLSI) Wayne (2013) criteria by culturing the coagulasepositive Staphylococcus aureus isolates on Muller Hinton agar plates to test their sensitivity to oxacillin $(1 \mu \mathrm{g})$ and cefoxitin $(30 \mu \mathrm{g})$, and incubation at $35^{\circ} \mathrm{C}$ for a full $24 \mathrm{~h}$ was done. Plates were observed carefully in transmitted light for any growth. Any growth after $24 \mathrm{~h}$ was considered oxacillin resistant. MRSA was identified when the diameter of the inhibition zone to oxacillin is $\leq 12 \mathrm{~mm}$ and for cefoxitin is $\leq 21 \mathrm{~mm}$ (Ferreira et al. 2012) (Fig. 2). Cefoxitin is a crucial back-up due to heteroresistance phenomenon, which stated that all cells in a culture may possess genes for resistance, but only a small number may express the resistance in vitro. This phenomenon is termed heteroresistance and occurs in staphylococci resistant to penicillinase-stable penicillins, such as oxacillin. However, cells expressing heteroresistance grow more slowly than the oxacillin-susceptible isolates and may be missed at temperatures above $35^{\circ} \mathrm{C}$. This is why CLSI recommends incubating isolates being tested against oxacillin or cefoxitin at $33-35^{\circ} \mathrm{C}$ (not more than $35^{\circ} \mathrm{C}$ ) for a full $24 \mathrm{~h}$ before reading (Wayne 2013).

The second step was DNA extraction from 12 MRSA isolates (resistant to both oxacillin and cefoxitin), 5 isolates

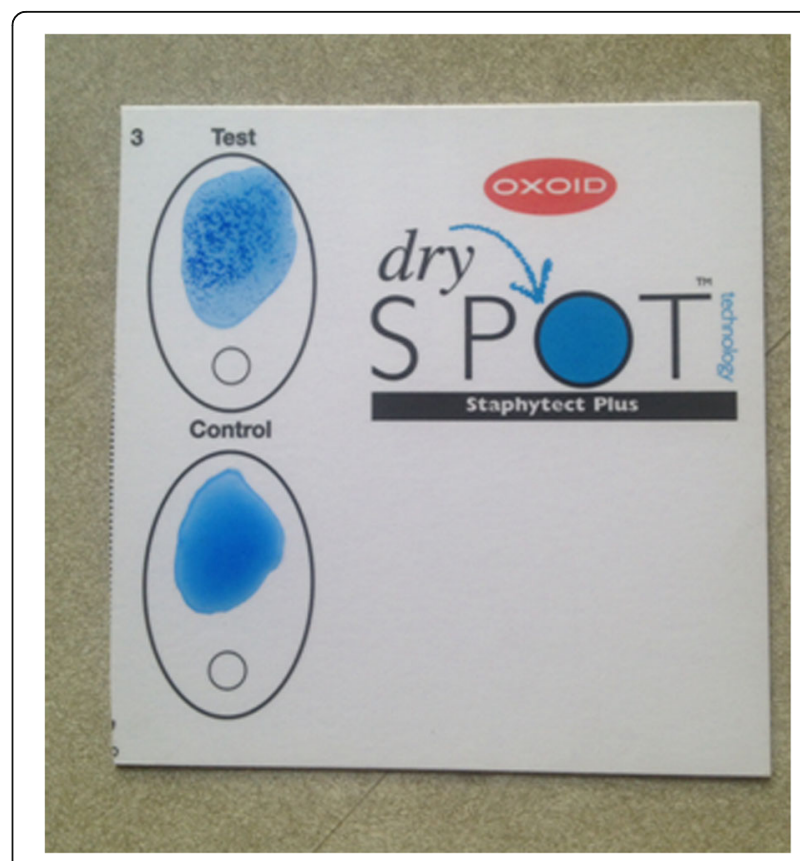

Fig. 1 Coagulase-positive Staphylococcus aureus 


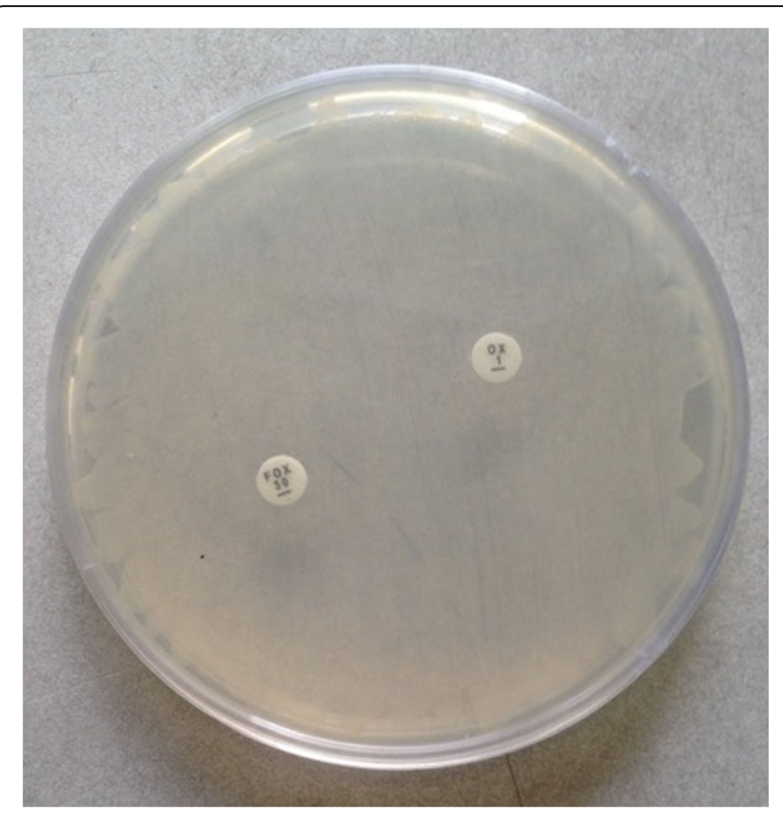

Fig. 2 Identification of MRSA. Coagulase positive S. aureus showed resistance to oxacillin $(1 \mu \mathrm{g}) \leq 12 \mathrm{~mm}$ and cefoxitin $(30 \mu \mathrm{g}) \leq 21 \mathrm{~mm}$ by disc diffusion method

which were resistant to oxacillin only, and 5 isolates which showed no resistance to any (sensitive to both oxacillin and cefoxitin); however, those last 10 isolates were studied for comparison as controls. Qiagen DNeasy kit (Qiagen, USA) was used for DNA extraction from bacterial cultures according to the manufacturer's instructions (Qiagen DNeasy handbook, July 2006) as follows.

Preparation of Qiagen Protease solution was done by adding $1.2 \mathrm{ml}$ protease solvent into the vial containing lyophilized Qiagen Protease and stored at $-20^{\circ} \mathrm{C}$. Buffer AL (lysis buffer) was mixed thoroughly by shaking before use and stored at room temperature. Buffer AW1 (wash buffer 1) and buffer AW2 (wash buffer 2) were supplied as a concentrate before using for the first time; appropriate amount of ethanol (96-100\%) was added and stored at room temperature.

The procedure was done by adding $20 \mu \mathrm{l}$ of Qiagen Protease into the bottom of a 1.5-ml microcentrifuge tube, and the bacterial suspension was added after heated at $100{ }^{\circ} \mathrm{C}$ for $10 \mathrm{~min}$. Two hundred microliters of buffer AL was added to the sample and mixed by pulsevortexing for $15 \mathrm{~s}$ then incubated at $56{ }^{\circ} \mathrm{C}$ until the suspension became clear. Two hundred microliters of ethanol $96 \%$ was added to the sample and mixed again then centrifuged. The mixture was applied to the QIAamp Mini spin column and centrifuged at $6000 \mathrm{rpm}$ for $1 \mathrm{~min}$; then, the column was placed in a clean 2-ml collection tube, and the tube containing the filtrate was discarded. Five hundred microliters of buffer AW1 was added and centrifuged for $1 \mathrm{~min}$ (same as above). Five hundred microliters of buffer AW2 was added and centrifuged at full speed 20,000 rpm for $3 \mathrm{~min}$. The QIAamp Mini spin column was placed in a new $2 \mathrm{ml}$ collection, and the old collection tube was discarded with the filtrate and centrifuged at full speed for $1 \mathrm{~min}$. The QIAamp Mini spin column was placed in a clean 1.5-ml micro-centrifuge tube, and the collection tube containing the filtrate was discarded and $200 \mu \mathrm{l}$ buffer $\mathrm{AE}$ was added and incubated at room temperature for $1 \mathrm{~min}$ then centrifuged for $1 \mathrm{~min}$.

The third step was the amplification of spa gene by polymerase chain reaction for the extracted 22 DNA. The primers used were:

Forward: 5 ATCTGGTGGCGTAACACCTG-3' and the reverse: 5-C GCTGCACCTAACGCTAATG-3 (Shakeri et al. 2010).

The reaction was carried out by Taq PCR Master Mix. The PCR mixture consisted of $1 \mathrm{mmol} / \mathrm{l}$ magnesium chloride, $0.2 \mathrm{mmol} / \mathrm{l}$ dNTPs, PCR buffer, $1 \mu \mathrm{mol} / \mathrm{l}$ of primers, and 1 unit of Taq-DNA polymerase in a final volume of $50 \mu \mathrm{l}$. Samples were denaturated at $94{ }^{\circ} \mathrm{C}$ for 4 min followed by 35 cycles using the following parameters: denaturation at $94{ }^{\circ} \mathrm{C}$ for $1 \mathrm{~min}$, annealing at $56^{\circ} \mathrm{C}$ for $1 \mathrm{~min}$, and extension at $72^{\circ} \mathrm{C}$ for $3 \mathrm{~min}$, with a final extension at $72{ }^{\circ} \mathrm{C}$ for $5 \mathrm{~min}$.

The fourth step was detection of the amplified product using agarose gel electrophoresis. Agarose gel was prepared by adding $2 \mathrm{~g}$ of agarose powder then dissolved in $100 \mathrm{ml}$ of Tris-acetate EDTA buffer, mixed thoroughly, and heated in the microwave until totally dissolved then left to cool down to $50{ }^{\circ} \mathrm{C}$. The agarose was then poured into the electrophoresis tray containing the comb fixed in place and left to cool at room temperature for $30 \mathrm{~min}$. Comb was removed from the solidified agarose and placed into the electrophoresis tray. Amplified samples were mixed with loading buffer, and each sample was dispensed into one well in the agarose gel (total volume 15-20 $\mu \mathrm{l}$ per well). Ladder was added in the first well of the agarose gel, and one drop of ethidium bromide was put per tray. The tray was covered with the electric electrodes cover. Reading was done under UV light gel documentation system.

\section{Results}

In the present study, 81 samples from healthcare providers in the hospital of the Research Institute of Ophthalmology (RIO), Egypt, were screened for MRSA. Out of these 81 samples, 41 isolates $(50.6 \%)$ were identified as coagulase-positive Staphylococcus aureus. Twelve staphylococcal isolates were resistant to both oxacillin and cefoxitin, and those were identified as MRSA with a percentage of $14.8 \%(12 / 81)$. Out of 12 MRSA DNA, spa gene could be detected in 10 of them by conventional PCR with a percentage of $83.3 \%$ (10/12) (Fig. 3). 


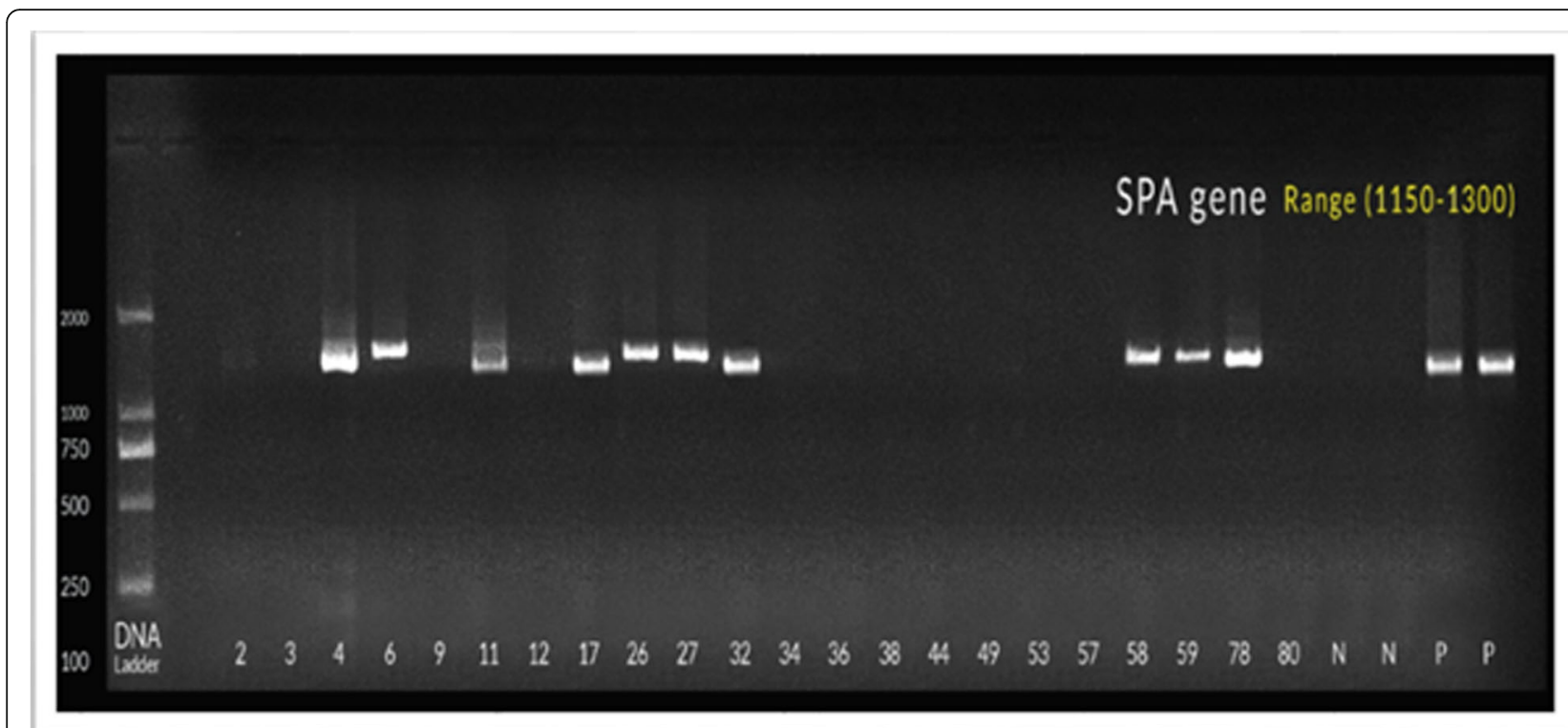

Fig. 3 Results of spa detection by PCR of 22 DNA. Twelve DNA isolated from MRSA, 5 oxacillin-R only, and 5 not oxacillin-R nor cefoxitin-R

\section{Discussion}

In the present study, the prevalence of Staphylococcus aureus was $50.6 \%$ (41/81) among healthcare workers (HCWs) providing nasal swabs, and the prevalence of MRSA was $14.8 \%(12 / 81)$.

Regarding the prevalence of Staphylococcus aureus, Price et al. (2017) observed during their study that 58\% of healthcare workers yielded $S$. aureus at least once from nasal swabs; however, their results are more than ours. While Sakr et al. (2018) reported that Staphylococcus aureus permanently colonized up to $30 \%$ of asymptomatic humans and although it is a commensal of the nose and skin, yet it may induce opportunistic and even life-threatening infections such as surgical site infections (SSIs). However, their results are lower than ours.

Chuang et al. (2012) in their 10 years retrospective study in Chang Gung Memorial Hospital, Taiwan, determined that MRSA account for $52.8 \%$ of ocular S. aureus infections per year with nearly half of ocular MRSA infections were sight-threatening, while in the USA, Weiner et al. (2013) reported that MRSA accounts for about $30 \%$ of all severe $S$. aureus eye infections, and the percentage is rising every year. American Nurse Today (2010) reported that about one third of the general population harbor staphylococci and the carrier status of healthcare workers ranges from 50 to $90 \%$ of which the commonest site is the anterior nares. They also reported that MRSA is able to withstand or recover quickly from difficult conditions and able to live outside the host for some time which is not exactly known. Smith (2008) reported that 1 in every 20 healthcare workers was MRSA carrier (5\%) and stated that healthcare workers are usually vectors, rather than the main sources of MRSA transmission.
Parks and Croce (2012) estimated an elevated percentage of asymptomatic carriers of MRSA in the general population to be $5-10 \%$; they stated that in spite of possible decreasing in the percentage of MRSA infections in hospitals, yet it is of great concern as asymptomatic carriers might be exposed to skin and soft tissues infections, including serious surgical site infections (SSIs). The same average was also obtained by Nair and coauthors (2013) when they investigated $251 \mathrm{~S}$. aureus isolates that were collected by the National Center for Communicable Diseases (NCCD) in Ulaanbaatar, Mongolia, and demonstrated methicillin resistance in $8.8 \%$ of isolates $(22 / 251)$. Dulon et al. (2014) estimated the prevalence of MRSA in HCWs to be $4.6 \%$, predicting that MRSA carriage in HCWs in non-outbreak settings is thought to be higher than in an outbreak situation, due to increased hygiene awareness in outbreaks. However, they found that MRSA prevalence among HCWs in non-outbreak settings was not higher than carriage rates estimated for outbreaks. Similar results were published by Sassmannshausen et al. (2016) who investigated MRSA prevalence and the risk factors for MRSA colonization among HCWs by gathering nasopharyngeal swabs from 9 hospitals with different care levels within the German part of a Dutch-German border region (EUREGIO). Spa typing of the isolated MRSA strains was done, and the overall MRSA prevalence among HCWs in a non-outbreak situation was $4.6 \%$; it was higher in nurses $(5.6 \%)$ than in physicians $(1.2 \%)$. However, the results in the present study are higher than all of them. Very recently in the USA, Kavanagh et al. (2018) reported the carriage rate of $S$. aureus in the general population approximates $33 \%$ and that of MRSA is approximately $2 \%$ as estimated by the CDC; still, the carriage rate of MRSA 
in healthcare workers approximates 5\% with concerns of transmission of this pathogen to patients. Also, these recent results reported by Kavanagh et al. (2018) are lower than our results regarding $S$. aureus and MRSA.

On the other hand, in Iran, a study was done by Shakeri et al. (2010) reported the prevalence of MRSA from healthy carriers and patients as $28 \%$. A higher prevalence of MRSA was reported later by Afrough et al. (2013) as $52.5 \%$ in staff and $83.7 \%$ in patients' specimens. More recent study in a burn hospital in Tehran by Abbasian et al. (2018) reported MRSA prevalence as $50 \%$ among $\mathrm{HCWs}$ and $64.2 \%$ among patients. And hence, all three studies in Iran showed higher MRSA prevalence than the prevalence in the present study which was $14.8 \%$.

When comparing an old method of MRSA typing which was phage typing with more recent molecular techniques as spa typing the latter is more sensitive allowing differentiation of strains within a particular phage type (Frénay et al. 1996). MRSA typing is a crucial step for an effective surveillance system to outline epidemiological trends and infection control strategies. Therefore, it is important to focus on choosing the proper technique in terms of accuracy, authenticity, simplicity, clarity, and cost-effectiveness regarding MRSA typing (Mehndiratta and Bhalla 2012).

Amplification of spa gene by PCR is a necessary preliminary step for spa typing of MRSA. In the present study, the results of detection of spa gene in MRSA DNA by conventional PCR were $83.3 \%$ (10/12).

Different primer sequences for detection of spa gene by PCR have been used in different parts of the world. However, although we used the same primer sequences and the same thermal cycling reaction conditions that Shakeri et al. (2010) had used for spa gene detection by conventional PCR, yet we could not detect spa gene in $16.7 \%$ of the DNA MRSA while their percentage was much lower as $3.4 \%$ only. Meanwhile, they found that frequencies of strains with short spa bands in strains isolated from patients were significantly more than those isolated from healthy carriers, and they concluded that the length of spa gene depends either on resistance to methicillin or the source of $S$. aureus isolation, while in earlier study by Koreen et al. (2004) suggested that repeat composition and organization, and not the number of repeats, allow spa typing to correlate with the DNA microarray data. Peacock et al. (2002) detected spa gene by PCR in $90 \%$ of $S$. aureus isolated from carriers which was a better result than in the present study as $83.3 \%$; they reported the presence of different gene codes for virulence in natural populations of $S$. aureus and clarified that the effect of those genes were separately increasing the chances for a disease and reported that it might be inaccurately to regard virulence in relation to the presence or absence of a given bacterial factor. It is worthwhile to mention that they used different primers than that used in the present study. Baum et al. (2009) also used different primers to analyze eight non-spa-typeable strains that were isolated from blood cultures of patients with invasive $S$. aureus infections in Denmark; however, they found that only two strains actually failed to give a positive result, suggesting that those two strains were true spa-deficient strains.

They concluded that mutations in the primer binding region might have missed spa-positive strains. They also concluded that in spite of spa having a strong role in the pathogenesis of $S$. aureus infections, the two spa-deficient strains were isolated from patients with severe $S$. aureus-related infections, denoting that the strains were still virulent and invasive in spite of being spa-deficient. That was confirmed later in a study also made in Denmark as part of the national surveillance of $S$. aureus bacteraemia and MRSA by Sorum et al. (2013); sequencing of the whole spa including the promoter region was amplified by PCR using three different primer sets, which included primers previously described by (Strommenger et al. 2006) and their novel primers. They notice naturally occurring mutants secreting spa into the extracellular environment were sporadically present among isolates involved in disease and carriage, suggesting that cell wall-bound Staphylococcus protein A is not necessary for survival and virulence of $S$. aureus in the host. They stated that with the plenty and overflow of virulence factors in S. aureus, including surface proteins removing just one factor is not necessarily enough to leave this bacterium unable to cause disease.

Votintseva and coauthors (2014) designed an improved primers that were capable of sequencing of all strains, containing any type of genetic rearrangement, in a large study among community carriers and hospital inpatients in Oxfordshire, UK, three of these rearrangements would be designated non-typeable using current spa-typing methods; they occurred in $1.8 \% \mathrm{~S}$. aureus strains isolated from asymptomatic carriers and in $0.6 \%$ strains isolated from patients. They concluded that a weakness of current spa-typing primers is that rearrangements in the IgG-binding region of the gene cause $1-2 \%$ of strains to be designated as non-typeable and accounting for hidden diversity of $S$. aureus in both community and hospital environments.

\section{Conclusion}

In the present study, the prevalence of MRSA in HCWs was $14.8 \%$. Since amplification of spa gene by PCR is a necessary preliminary step for spa typing of MRSA and since using different primers for spa gene amplification might affect PCR results, then proper selection of the primers and thermal cycling reaction conditions are recommended for PCR performance and spa typing. 


\section{Abbreviations}

CA: Community-associated; CDC: Centers for disease control; CLSI: Clinical Laboratory Standards Institute; FclgG: Fragment crystallizable of immunoglobulin G; HA: Healthcare-associated; HCWs: Health care workers; MRSA: Methicillin-resistant Staphylococcus aureus; PCR: Polymerase chain reaction; Ptn A: protein A; RIO: Research Institute of Ophthalmology; spa: Surface protein A of Staphylococcus aureus; SSIs: Surgical site infections

\section{Acknowledgements}

The authors would like to thank the infection control team and healthcare workers in the Research Institute of Ophthalmology (RIO) and Prof. Ali Zaki, Professor of Microbiology Ain Shams University, for his help in the molecular work.

\section{Authors' contributions}

$\mathrm{MH}$ designed the plan of the work, participated in lab work, and wrote and submitted the manuscript. AA participated in the lab work and shared in writing it and participated in the development and implementation of the research plan. MA participated in the lab work and shared writing lab work. All authors read and approved the final manuscript.

\section{Funding}

The expenses were paid by the authors.

\section{Availability of data and materials}

The materials and the generated and analyzed data during this study are included in this published article.

\section{Ethics approval and consent to participate}

The work is ethically approved by the Scientific Research Committee of the Research Institute of Ophthalmology RIO, Egypt, prior to the beginning of the study. Nasal swab samples used in the study were obtained after individuals' consent.

\section{Consent for publication}

Not applicable.

\section{Competing interests}

The authors declare that they have no competing interests.

\section{Author details}

'Microbiology \& Immunology Unite, Research Institute of Ophthalmology, 2 El Ahram Street, Giza 12557, Egypt. ${ }^{2}$ Allergy lab, Research Institute of Ophthalmology, 2 El Ahram Street, Giza 12557, Egypt. ${ }^{3}$ Infection Control Unit, Research Institute of Ophthalmology, Giza, Egypt.

Received: 27 March 2019 Accepted: 11 December 2019

Published online: 27 December 2019

\section{References}

Abbasian S, Farahani NN, Mir Z, Alinejad F, Haeili M, Dahmardehei M et al (2018) Genotypic characterization of Staphylococcus aureus isolated from a burn centre by using agr, spa and SCCmec typing methods. New Microbes New Infect 26:15-19. https://doi.org/10.1016/j.nmni.2018.08.001

Afrough P, Pourmand MR, Sarajian AA, Saki M, Saremy S (2013) Molecular investigation of Staphylococcus aureus, coa and spa genes in Ahvaz City hospitals staff nose compared with patients clinical samples. Jundishapur J Microbiol 6(4):e5377. https://doi.org/10.5812/jjm.5377

American Nurse Today June 2010 Vol. 5 No. 6. MRSA: A growing threat in both community and healthcare settings

Baum C, Haslinger-Löffler B, Westh H, Boye K, Peters G, Neumann C (2009) Nonspa-typeable clinical Staphylococcus aureus strains are naturally occurring protein A mutants. J Clin Microbiol. https://doi.org/10.1128/JCM.00941-09

Chuang C-C, Hsiao C-H, Tan H-Y, Ma DH-K, Lin K-K, Chang C-J et al (2012) Staphylococcus aureus ocular infection: methicillin-resistance clinical features and antibiotic susceptibilities. PLoS One 7(8):e42437. https://doi.org/10.1371/ journal.pone.0042437

Dulon M, Peters C, Schablon A, Nienhaus A (2014) MRSA carriage among healthcare workers in non-outbreak settings in Europe and the United States: a systematic review. BMC Infect Dis 14:363. https://doi.org/10.1186/14712334-14-363
El-Mishad AM (2011) Manual of Medical Microbiology \& Immunology Part II

Fasihi Y, Fooladi S, Mohammadi MA, Emaneini M, Kalantar-Neyestanaki D (2017) The spa typing of methicillin-resistant Staphylococcus aureus isolates by High Resolution Melting (HRM) analysis. J Med Microbiol 66:1335-1337. https://doi. org/10.1099/jmm.0.000574

Ferreira AM,Bonesso MF, Mondelli AL, Camargo CH, Cunha MLRS. Oxacillin resistance and antimicrobial susceptibility profile of Staphylococcus Saprophyticus and other staphylococci isolated from patients with urinary tract infection. Chemotherapy 2012;58:482-491

Fournier JM, Boutonnier A, Bouvet A (1989) Staphylococcus aureus strains which are not identified by rapid agglutination methods are of capsular serotype 5 . J Clin Microbiol 27:1372-1374

Frénay HM, Theelen JP, Schouls LM, Vandenbroucke-Grauls CM, Verhoef J, VanLeeuwen WJ et al (1994) Discrimination of epidemic and nonepidemic methicillin-resistant Staphylococcus aureus strains on the basis of protein A gene polymorphism. J Clin Microbiol 32(3):846-847

Frénay HM, Bunschoten AE, Schouls LM, Van-Leeuwen WJ, Vandenbroucke-Grauls CM, Verhoef J et al (1996) Molecular typing of methicillin-resistant Staphylococcus aureus on the basis of protein A gene polymorphism. Eur J Clin Microbiol Infect Dis 15(1):60-64

Gordon RJ, Lowy FD (2008) Pathogenesis of methicillin-resistant Staphylococcus aureus infection. Clin Infect Dis 46(Suppl 5):350-359

Harmsen D, Claus H, Witte W, Rothgänger J, Claus H, Turnwald D et al (2003) Typing of methicillin-resistant Staphylococcus aureus in a university hospital setting by using novel software for spa repeat determination and database management. J Clin Microbiol 41:5442-5448

Kavanagh KT, Abusalem S, Calderon LE (2018) View point: gaps in the current guidelines for the prevention of Methicillin-resistant Staphylococcus aureus surgical site infections. Antimicrob Resist Infect Control 7:112. BioMed Central Published online 2018 Sep 18. https://doi.org/10.1186/s13756-018-0407-0

Keener AB, Thurlow LT, Kang SA, Spidale NA, Clarke SH, Cunnion KM et al (2017) Staphylococcus aureus protein A disrupts immunity mediated by long-lived plasma cells. J Immunol 198(3):1263-1273. https://doi.org/10.4049/jimmunol.1600093

Kobayashi SD, DeLeo FR (2013) Staphylococcus aureus protein A promotes immune suppression. mBio 4(5):e00764-13. https://doi.org/10.1128/mBio.00764-13

Koreen L, Ramaswamy SV, Graviss EA, Naidich S, Musser JM, Kreiswirth BN (2004) Spa typing method for discriminating among staphylococcus aureus isolates: implications for use of a single marker to detect genetic micro- and macrovariation. J Clin Microbiol 42(2):792-799

Liu Y, Zhang J, Ji Y (2016) PCR-based approaches for the detection of clinical methicillin-resistant Staphylococcus aureus. Open Microbiol J 10(Suppl 1M2): 45-56. https://doi.org/10.2174/1874285801610010045

Mehndiratta P, Bhalla P (2012) Typing of methicillin resistant Staphylococcus aureus: a technical review. Indian J Med Microbiol 30(1):16-23. https://doi. org/10.4103/0255-0857.93015

Nair R, Hanson BM, Kondratowicz K, Dorjpurev A, Davaadash B, Enkhtuya B et al (2013) Antimicrobial resistance and molecular epidemiology of Staphylococcus aureus from Ulaanbaatar, Mongolia. PeerJ 1:e176. https://doi. org/10.7717/peerj.176

Parks NA, Croce MA (2012) Routine screening for methicillin-resistant Staphylococcus aureus. Surg Infect 13(4):2237-2237. https://doi.org/10.1089/ sur.2012.130 Epub 2012 Aug 22

Peacock SJ, Moore CE, Justice A, Kantzanou M, Story L, Mackie K et al (2002) Virulent combinations of adhesin and toxin genes in natural populations of Staphylococcus aureus. Infect Immun 70:4987-4996

Price JR, Cole K, Bexley A, Kostiou V, Eyre DW, Golubchik T et al (2017) Transmission of Staphylococcus aureus between health-care workers the environment and patients in an intensive care unit: a longitudinal cohort study based on whole-genome sequencing. Lancet Infect Dis 17(2):207-214. https://doi.org/10.1016/S1473-3099(16)30413-3

QIAgen, DNeasy ${ }^{\oplus}$ Blood \& Tissue Handbook, July 2006; pp: 45. WWW.QIAGEN COM.

Ritterband D (2013) Methicillin-resistant Staphylococcus aureus and the eye: current concepts and management strategies. Curr Ophthalmol Rep 1(4): 151-160. https://doi.org/10.1007/s40135-013-0030-4

Sakr A, Brégeon F, Mège JL, Rolain JM, Blin O (2018) Staphylococcus aureus nasal colonization: an update on mechanisms, epidemiology, risk factors, and subsequent infections. Front Microbiol 9:2419. https://doi.org/10.3389/fmicb. 2018.02419

Sassmannshausen R, Deurenberg RH, Köck R, Hendrix R, Jurke A, Rossen JWA et al (2016) MRSA prevalence and associated risk factors among health-care 
workers in non-outbreak situations in the Dutch-German EUREGIO. Front Microbiol 7:1273. https://doi.org/10.3389/fmicb.2016.01273

Shakeri F, Shojai A, Golalipour M, Alang SR, Vaez H, Ghaemi EA (2010) Spa diversity among MRSA and MSSA strains of Staphylococcus aureus in North of Iran. Int J Microbiol Hindawi Publishing Corporation:351397, 5 pages. https://doi.org/10.1155/2010/351397

Smith M (2008) One in every 20 healthcare workers is MRSA carrier. MedPage Today April 15

Sørum M, Sangvik M, Stegger M, Olsen RS, Johannessen M, Skov R et al (2013) Staphylococcus aureus mutants lacking cell wall-bound protein A found in isolates from bacteraemia, MRSA infection and a healthy nasal carrier. Pathog Dis 67(1):19-24. https://doi.org/10.1111/2049-632X.12017

Strommenger B, Kettlitz C, Weniger T, Harmsen D, Friedrich AW, Witte W (2006) Assignment of Staphylococcus isolates to groups by spa typing, Smal macrorestriction analysis, and multilocus sequence typing. J Clin Microbiol 44:2533-2540

Votintseva AA, Fung R, Miller RR, Knox K, Godwin H, Wyllie DH et al (2014) Prevalence of Staphylococcus aureus protein A (spa) mutants in the community and hospitals in Oxfordshire. BMC Microbiol 14:63

Wayne PA, CLSI (2013) Performance standards for antimicrobial susceptibility testing. CLSI approved standard M100-S23. Clinical and Laboratory Standards Institute

Weiner G, Blomquist PH, Durairaj VD, Hwang DG (2013) MRSA ophthalmic infection, part 1: current realities. American Academy of Ophthalmology EyeNet Magazine

\section{Publisher's Note}

Springer Nature remains neutral with regard to jurisdictional claims in published maps and institutional affiliations.

\section{Submit your manuscript to a SpringerOpen ${ }^{\circ}$ journal and benefit from:}

- Convenient online submission

- Rigorous peer review

- Open access: articles freely available online

- High visibility within the field

- Retaining the copyright to your article

Submit your next manuscript at $\boldsymbol{\nabla}$ springeropen.com 